Original research article

\title{
Effect of selected 8-hydroxyquinoline-2-carboxanilides on viability and sulfate metabolism of Desulfovibrio piger
}

\author{
Ivan Kushkevych ${ }^{\mathrm{a}, *}$, Monika Vítězováa ${ }^{\mathrm{a}}$, Jiří Kos ${ }^{\mathrm{b}}$, Peter Kollár ${ }^{\mathrm{c}}$, Josef Jampílek ${ }^{\mathrm{b}, * *}$ \\ a Masaryk University, Faculty of Science, Department of Experimental Biology, Brno, Czech Republic \\ ${ }^{\mathrm{b}}$ Comenius University, Faculty of Pharmacy, Department of Pharmaceutical Chemistry, Bratislava, Slovak Republic \\ ${ }^{\mathrm{c}}$ University of Veterinary and Pharmaceutical Sciences, Faculty of Pharmacy, Department of Human Pharmacology and Toxicology, Brno, Czech Republic
}

\section{A R T I C L E I N F O}

\section{Article history:}

Received 3 August 2017

Received in revised form 5 January 2018

Accepted 15 January 2018

Available online 10 February 2018

\section{Keywords:}

Sulfate-reducing bacteria

Dissimilatory sulfate reduction

Inflammatory bowel disease

8-hydroxyquinolines

Structure-activity relationships
A B S T R A C T

An increased number of sulfate-reducing bacteria is often isolated from faeces of patients with gastrointestinal diseases, which can be the cause of the development of bowel inflammation. Frequent use of antibiotics causes the resistance of intestinal microorganisms and ineffective treatment of these diseases. The antimicrobial activity and biological properties of the selected ring-substituted 8-hydroxyquinoline-2-carboxanilides against Desulfovibrio piger Vib-7 were studied. The addition of these compounds in the cultivation medium inhibited the bacterial growth and the process of sulfate reduction dose-dependently. A significant cytotoxic activity under the influence of ring-substituted 8-hydroxyquinoline-2-carboxanilides was determined. The strongest cytotoxic effect of the derivatives was observed for compounds 8-hydroxy- $N$-(3-methoxyphenyl)quinoline-2-carboxamide and 8-hydroxy- $\mathrm{N}$-(3-trifluoromethylphenyl)quinoline-2-carboxamide that caused a low survival of $D$. piger Vib-7 in concentration $17 \mu \mathrm{M}$ and high toxicity rates.

(C) 2018 Faculty of Health and Social Sciences, University of South Bohemia in Ceske Budejovice. Published by Elsevier Sp. z o.o. All rights reserved.

\section{Introduction}

A high number of sulfate-reducing bacteria (SRB) and the intense process of dissimilatory sulfate reduction in the gut are thought to be significant risk factors of inflammatory bowel diseases in both humans and animals (Gibson et al., 1991, 1993; Kushkevych, 2016, Kushkevych et al., 2016). These bacteria are often found in patients with rheumatic diseases, ankylosing spondylitis, etc. (Barton and Hamilton, 2010). The species of Desulfovibrio genus can cause bloody diarrhea, weight loss, anorexia, epithelial hyperplasia, abscesses and inflammatory infiltrates in animals and humans (Loubinoux et al., 2000, 2002a,b). There is also an assumption that SRB can be responsible for some forms of cancer of the rectum through the formation of hydrogen sulfide that affects the metabolism of intestinal cells.

\footnotetext{
* Author for correspondence: Masaryk University, Faculty of Science, Department of Experimental Biology, Kamenice 753/5, 62500 Brno, Czech Republic.

** Author for correspondence: Comenius University, Faculty of Pharmacy, department of Pharmaceutical Chemistry, Odbojarov 10, 83232 Bratislava, Slovak Republic.

E-mail addresses: kushkevych@mail.muni.cz (I. Kushkevych), josef.jampilek@gmail.com (J. Jampílek).
}

An increased number of SRB was found in faeces from people with ulcerative colitis in comparison with healthy individuals (Cummings et al., 2003). The injection of these bacteria in hamster intestine caused an infection clinically similar to human colitis (Cummings et al., 2003; Pitcher and Cummings, 1996). Using the model of laboratory rats, the etiological role of the cultures of SRB, Desulfovibrio piger Vib-7 and Desulfomicrobium sp. Rod-9, in the development of inflammatory processes in the intestine was examined. It was found that the introduction of pure cultures of SRB led to a high production of hydrogen sulfide and acetate in the intestine, and clinical manifestations similar to nonspecific intestinal inflammation in humans appeared (Kushkevych, 2014).

Ulcerative colitis (UC) is a chronic inflammatory disease of the colon that affects up to 12 per 100,000 people in Western countries, mostly between 15 and 30 years of age (Rowan et al., 2009). The treatment of mild to moderate UC includes, in the first instance, sulfasalazine and mainly 5-aminosalicylate containing drugs, the type and dosage of which depend on the location and severity of the disease. Other options of treatment include corticosteroids and immunosuppressants (for moderate to severe UC, with a high mortality) or probiotics (for improving the microbial balance) (Cummings et al., 2003; Kushkevych, 2016). Despite the bacterial nature of the disease, antibiotics have failed 
in the treatment of UC so far. However, new antibacterial compounds with high specific effect against SRB could yield better efficiency in the treatment of this disease.

Quinoline-based compounds have a wide range of promising biological properties (Cieslik et al., 2012; Jampilek, 2017; Jampilek et al., 2016, Kos et al., 2015; Mucaji et al., 2017; Musiol et al., 2006, $2007,2008,2010$ ); therefore a special attention is paid to them at research and designing of new drugs (Cieslik et al., 2012; Jampilek et al., 2016; Kos et al., 2015; Musiol et al., 2006, 2007; Ranjith et al., 2017). This simple scaffold possesses unique physicochemical properties and provides a possibility of a great number of targeted modifications. Ring-substituted 8-hydroxyquinoline-2-carboxanilides were recently prepared (Kos et al., 2015) and published as compounds with noteworthy biological activities (Jampilek et al., 2016; Kos et al., 2015) based on the presence of an amide group and a hydroxy moiety in the quinoline scaffold (Gonec et al., 2012; Jampilek et al., 2016; Kos et al., 2015). Thus, in the context of the above-mentioned facts, the aim of this work was to evaluate viability of intestinal sulfate-reducing bacteria Desulfovibrio piger and parameters of their dissimilatory sulfate reduction (production of hydrogen sulfide and acetate as well as sulfate and lactate consumption) under effect of selected 8-hydroxyquinoline-2carboxanilides (Kos et al., 2015).

\section{Materials and methods}

\section{Tested compounds}

The studied ring-substituted 8-hydroxyquinoline-2-carboxanilides were synthesized by means of microwave-assisted synthesis described recently. The compounds were isolated and fully characterized (melting point, elemental analysis, infrared as well as ${ }^{1} \mathrm{H}$ and ${ }^{13} \mathrm{C}$ NMR spectroscopy) (Kos et al., 2015). The compounds were kept in microtubes dissolved in dimethyl sulfoxide (DMSO) solution. The quantity of DMSO necessary to dissolve each compound was calculated previously to achieve the concentration of the component $30 \mathrm{mM}$. Afterwards it was diluted 4 -fold in a proportion $1: 3$, and 5 different concentrations of the chemical compound - 5, 10, 15, 20, 25, 30 and $35 \mathrm{mM}$ - were obtained. The maximum concentration of DMSO in the assays never exceeded $0.1 \%$.

\section{Bacterial culture and cultivation}

The sulfate-reducing bacteria $D$. piger Vib-7 (GenBank: KT881309.1) were isolated from the healthy human large intestine as described previously (Kushkevych, 2013; Kushkevych et al., 2014). The strain has been kept in the collection of microorganisms at the Department of Experimental Biology, Faculty of Science at the Masaryk University (Brno, Czech Republic). The bacteria were grown for $36 \mathrm{~h}$ at $37^{\circ} \mathrm{C}$ under anaerobic conditions in nutrition modified Postgate's liquid medium (Postgate, 1984). Before bacterial passage in the medium, $0.05 \mathrm{mM}$ of sterile solution of $\mathrm{Na}_{2} \mathrm{~S} \times 9 \mathrm{H}_{2} \mathrm{O}(1 \%)$ was added. The sterile $10 \mathrm{ml}$ solution of $\mathrm{NaOH}(0.9 \mathrm{mM})$ in the medium was used to provide the final $\mathrm{pH}$ 7.2. The medium was heated in boiling water for $30 \mathrm{~min}$ in order to obtain an oxygenfree medium and cooled to $30^{\circ} \mathrm{C}$. The tubes were brim-filled with medium and closed to provide anaerobic conditions.

\section{Assay of bacterial cell concentration}

The best concentration of $D$. piger Vib-7 was assessed to be $5 \times 10^{5} \mathrm{CFU} / \mathrm{ml}$. Based on our previous work, the correlation between $\mathrm{OD}_{340}$ and the amount of cells in the solutions measured in the biophotometer was determined as $y=1.0 \times 10^{9} \chi-6.0 \times 10^{6}$, where $y$ means the bacterial concentration and $\chi$ means the $\mathrm{OD}_{340}$ measured as was described in our previous paper (Kushkevych et al., 2015a).

\section{Treatment of bacterial culture}

The bacterial culture of the stationary phase of growth was centrifuged for $3 \mathrm{~min}$ at a rotation speed of $3500 \mathrm{rpm}$. Supernatant was removed and replaced by a fresh liquid medium, where the bacterial precipitate was diluted. The bacterial suspension was mixed, and $\mathrm{OD}_{340}$ was measured. Numbers and viabilities of the bacterial cells were determined by counting with a haemocytometer after staining with erythrosine $\mathrm{B}[0.1 \%$ erythrosine $\mathrm{B}(\mathrm{w} / \mathrm{v})$ in phosphate-buffered saline (PBS), $\mathrm{pH}$ 7.2-7.4]. Unstained cells were considered to be viable.

The bacterial suspension (initial concentration $0.5 \mathrm{mg} / \mathrm{ml}$ ) was poured in microtubes $(350 \mu \mathrm{l})$ that contained samples + solvent control (DMSO) + sample control + blanks; each sample as well as the controls were prepared in triplicate, so that the average of the results did not had a great discrepancy from the results independently (except in 3 blanks). The sample controls contained only bacterial suspension and medium (free of tested compounds); and for the 3 blanks only medium. Calculations were made to assess how much bacterial solution should be in each, based on the OD. The determination of biomass and concentrations of sulfate, lactate, acetate and sulfide in the culture medium under the treatment of 5,10,15,20, 25, 30 and $35 \mu \mathrm{M}$ compounds after $36 \mathrm{~h}$ was carried out. During experiments, bacteria were grown at $37^{\circ} \mathrm{C}$ under anaerobic conditions.

Analysis of viability of D. piger Vib-7 and cytotoxicity of compounds

The bacterial suspension $\left(5 \times 10^{4}\right.$ cells/well in $300 \mu$ l culture medium) was filled in 100-well plates in triplicate in the Postgate's liquid medium (without Mohr's salt), treated with 5, 10, 15, 20, 25, 30 and $35 \mu \mathrm{M}$ compounds and incubated at $+37^{\circ} \mathrm{C}$. The relative survival of $D$. piger Vib-7 cells and the cytotoxicity of the compounds were determined at the 36th hour of cultivation using a WST-1 assay kit (Roche Diagnostics, Mannheim, Germany) according to the manufacturer's instructions. The relative survival rate was calculated by the following equation: $\left(A_{\text {Sample }}-A_{\text {Blank }}\right) /$ ( $\left.A_{\text {Control }}-A_{\text {Blank }}\right)$, and multiplied by 100 for the result in percentage. The relative toxicity rate was determined as described previously (Kos et al., 2015). All data were evaluated using GraphPad Prism 5.00 software (GraphPad Software, San Diego, CA, USA, http:// www.graphpad.com).

Assay of sulfate, lactate, sulfide and acetate in cultivation medium

The sulfate ion concentration in the medium was determined by the turbidimetric method after it had been precipitated by barium chloride. To stabilize the suspension, glycerol was used (Kolmert et al., 2000). Lactate concentration was measured through the dehydrogenation reaction using Lactate Assay Kit (Sigma-Aldrich, Catalog Number MAK064). Sulfide concentration in the culture medium was assayed by the spectrophotometric method as was described (Cline, 1969). Accumulation of acetate ions in the process of bacterial growth in the medium was determined using Acetate Assay Kit (Colorimetric, Catalog Number KA3764).

\section{Statistical analysis}

The statistical calculations of the results were carried out using the software MS Office and Origin program. The research results were treated by methods of variation statistics using Student $t$-test. 
Statistical significance was tested using the one-way analysis of variance with Dunnett's test and Tukey post-test for comparisons between the means, and differences between two conditions were retained for $P \leq 0.05$. Statistical significance was determined at levels of $P<0.05, P<0.01$, and $P<0.001$ (Bailey, 1995).

\section{Results}

The structures of the selected and discussed ring-substituted 8-hydroxyquinoline-2-carboxanilides are shown in Table 1. A synthetic pathway and characterization were published by Kos et al. (2015).

The relative survival of $D$. piger Vib-7 cells and cytotoxicity of ring-substituted 8-hydroxyquinoline-2-carboxanilides were studied. In this series of experiments, compounds 1-7 exerted cytotoxicity against these bacteria already in low $(5-35 \mu \mathrm{M})$ concentrations (Fig. 1).

Treatment with all tested compounds led to a significant dose-dependent activity with the strongest effect observed in compounds $3\left(\mathrm{R}=3-\mathrm{OCH}_{3}\right)$ and $6\left(\mathrm{R}=3-\mathrm{CF}_{3}\right)$. Since some of ring-substituted 8-hydroxyquinoline-2-carboxanilides (such as $\mathbf{3}$ or 6) have a pronounced antimicrobial effect against D. piger Vib-7 (combination of low survival and high toxicity rates), they could be considered as promising agents against the growth of this type of bacteria.

The effect of different concentrations of ring-substituted 8-hydroxyquinoline-2-carboxanilides on the process of dissimilatory sulfate reduction in $D$. piger Vib-7 cells at the 36th h of cultivation was studied. As shown in Figs. 2 and 3, the addition of the compounds in the culture medium inhibits the process of dissimilation of sulfate directly proportional to the increase in concentrations $(5-35 \mu \mathrm{M})$. Under these conditions, the utilization of sulfate and lactate was inhibited; hence the level of accumulation of hydrogen sulfide and acetate was reduced. These data are consistent with our research in previous series of the experiments. The percentage inhibition of sulfate reduction process correlates with the percentage of bacterial growth inhibition under the ring-substituted 8-hydroxyquinoline-2carboxanilides treatment.

Based on the obtained results, the MIC and $\mathrm{IC}_{50}$ values of ring-substituted 8-hydroxyquinoline-2-carboxanilides against intestinal sulfate-reducing bacteria were established. As shown in Table 1 , the MICs of all the compounds were $\leq 33 \mu \mathrm{M}$. The

Table 1

Structures of ring-substituted 8-hydroxyquinoline-2-carboxanilides and in vitro antibacterial activity against Desulfovibrio piger Vib-7 (minimal inhibition concentration: $\mathrm{MIC}$, half maximal inhibitory concentration: $\mathrm{IC}_{50}$, minimal bactericidal concentration: $\mathrm{MBC}$ ) of the compounds in comparison with ciprofloxacin (CPX).

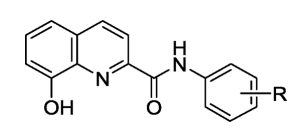

\begin{tabular}{|c|c|c|c|c|}
\hline \multirow[t]{2}{*}{ Comp. } & \multirow[t]{2}{*}{$\mathrm{R}$} & \multicolumn{3}{|c|}{$[\mu \mathrm{M}]$} \\
\hline & & MIC & $\mathrm{IC}_{50}$ & MBC \\
\hline 1 & $\mathrm{H}$ & 23 & 12 & 25 \\
\hline 2 & $2-\mathrm{OCH}_{3}$ & 28 & 17 & 28 \\
\hline 3 & $3-\mathrm{OCH}_{3}$ & 17 & 11 & 20 \\
\hline 4 & $3-\mathrm{CH}_{3}$ & 23 & 10 & 23 \\
\hline 5 & $3-\mathrm{Br}$ & 33 & 18 & 35 \\
\hline 6 & $3-\mathrm{CF}_{3}$ & 17 & 10 & 20 \\
\hline 7 & $4-\mathrm{CF}_{3}$ & 20 & 10 & 22 \\
\hline $\mathrm{CPX}$ & - & 45 & 28 & 45 \\
\hline
\end{tabular}
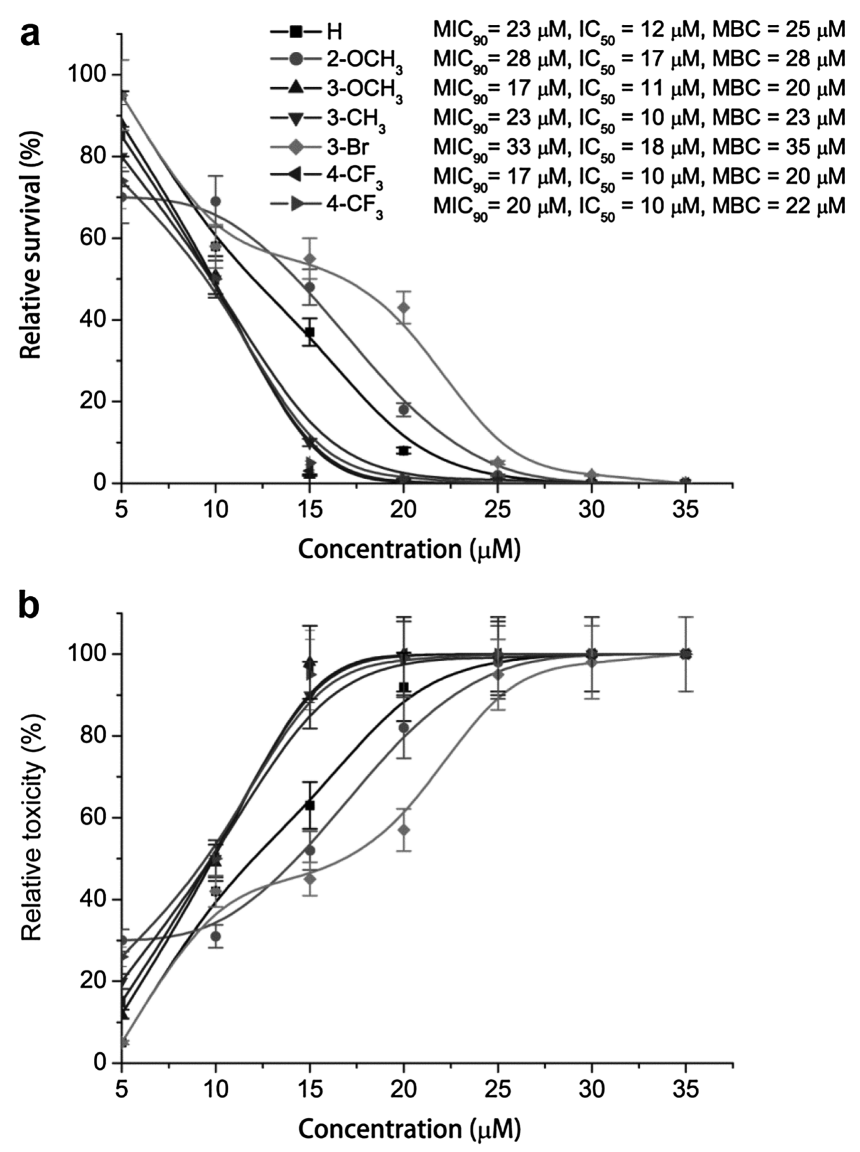

Fig. 1. Relative survival of D. piger Vib-7 cells (a) and toxicity (b) of ring-substituted 8-hydroxyquinoline-2-carboxanilides.

least potent compounds among the tested compounds for the bacterial strain were $\mathbf{2}\left(\mathrm{R}=2-\mathrm{OCH}_{3}\right)$ and $\mathbf{5}(\mathrm{R}=3-\mathrm{Br})$, the MICs of which were 28 and $33 \mu \mathrm{M}$, respectively. The similar MICs were determined for compounds $\mathbf{1}(\mathrm{R}=\mathrm{H})$ and $\mathbf{4}\left(\mathrm{R}=3-\mathrm{CH}_{3}\right)$. It can be supposed that these compounds show the same cytotoxicity effect on sulfate-reducing bacteria $D$. piger Vib-7 cells. $\mathrm{IC}_{50}$ of compounds 4, 6 and 7 was $10 \mu \mathrm{M}$. Compounds 2 and $\mathbf{5}$ had $\mathrm{IC}_{50}$ only 17 and $18 \mu \mathrm{M}$, which is consistent with the MICs of these compounds.

\section{Discussion and conclusion}

Sulfate-reducing bacteria of Desulfovibrio genus belong to the intestinal microbiota of humans and animals (Kushkevych, 2012, 2013). They are anaerobic microorganisms, dissimilating sulfate as an electron acceptor and organic compounds as an electron donor and carbon source in the process of "dissimilatory sulfate reduction" (also known as "dissimilatory anaerobic sulfate respiration") (Kushkevych, 2016). Lactate is the most common substrate used by the species belonging to the intestinal sulfatereducing bacteria. The species of Desulfovibrio oxidize lactate incompletely to acetate. Lactate oxidation to acetate occurs together with the concurrent reduction of sulfate to sulfide (Barton and Hamilton, 2010). The presence of lactate and sulfate in the human intestine contributes to the intensive bacteria growth and the accumulation of their final metabolic products, acetate and hydrogen sulfide, that are toxic, mutagenic and cancerogenic to epithelial intestinal cells (Pitcher and Cummings, 1996; Rowan et al., 2009). There is also an assumption that sulfate-reducing bacteria can cause some forms of cancer of the rectum through the 

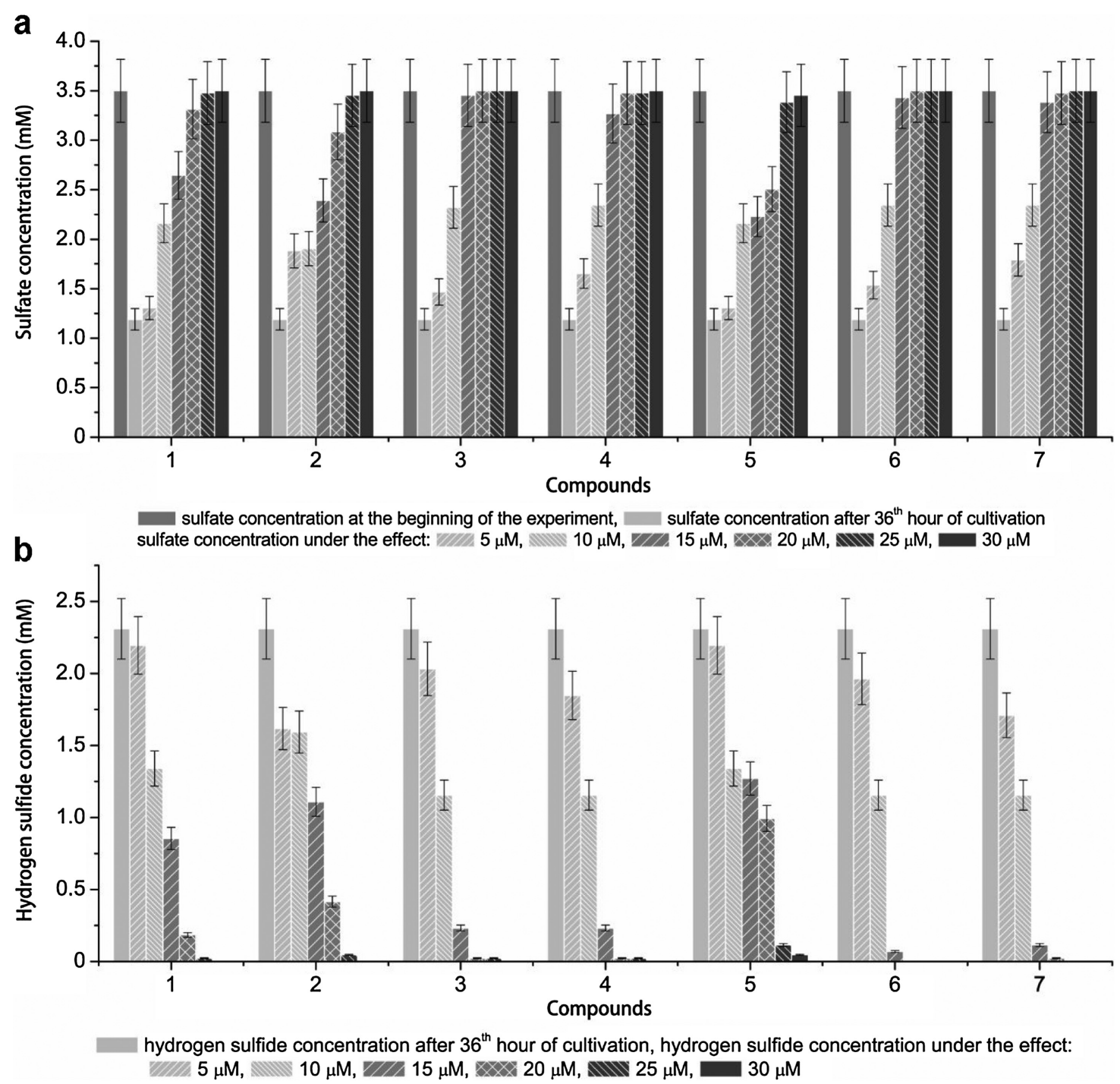

Fig. 2. Sulfate reduction of D. piger Vib-7 cells under the treatment of indicated doses of ring-substituted 8-hydroxyquinoline-2-carboxanilides: sulfate dissimilation (a), hydrogen sulfide production $(\mathbf{b})$.

formation of hydrogen sulfide. In our previous studies, it was shown that bacteria $D$. piger Vib-7 consumed sulfate and accumulated hydrogen sulfide in concentration of $2.31 \pm 0.21 \mathrm{mM}$ (Kushkevych, 2013).

Based on all the obtained results in this study, it can be concluded that compounds 1-7 in concentrations 5-35 $\mu \mathrm{M}$ inhibited the growth and, accordingly, the process of dissimilatory sulfate reduction. This antimicrobial activity was concentrationdependent, with the strongest effect in $30 \mu \mathrm{M}$ concentration. Similar effect was observed in our previous research for the activity of selected salicylamides against intestinal sulfate-reducing bacteria (Kushkevych et al., 2015a, 2016). Derivatives 1, 2, 4, 5 and $\mathbf{7}$ showed cytotoxic affect at concentrations higher than $17 \mu \mathrm{M}$. The highest level of inhibition of this process and high activity rates were observed at concentration $17 \mu \mathrm{M}$ of compounds $\mathbf{3}$ and $\mathbf{6}$ and thus are interesting for further studies. The cytotoxic effect of these compounds can be due to the inhibition of the enzymes of dissimilatory sulfate reduction (Kushkevych, 2015a,b; Kushkevych et al., 2015b), including sulfite reductase that is susceptible for various factors in intestinal sulfate-reducing bacteria D. piger Vib-7 (Kushkevych and Fafula, 2014). The tested compounds can be considered good alternatives for the treatment of colitis or colorectal cancer although it should be taken in account that these compounds can be aggressive also to commensally bacteria and even to other parts of the human body. This should be a concern to be clarified in the near future with complementary assays.

Despite the fact that evaluated bacteria Desulfovibrio species are heterogeneous group of microorganisms which are widespread in anaerobic areas of soils, wetlands, marine and fresh water, they are available in microbiota of large intestine of humans and animals. It is known that intestinal Desulfovibrio species are different from other SRB by their biochemical and physiological properties (Barton and Hamilton, 2010; Brenner et al., 2005; Holt et al., 1994). So, the mechanisms of the effect of studied compounds on these bacteria can also differ. These compounds may influence the synthesis of the bacterial cell wall (peptidoglycan), ribosomes, enzymes or other phenotypic features such as inhibition the synthesis of desulfoviridin, cytochrome c3 and menaquinone MK-6. Effect of studied compounds may depend on their activity, structure and properties. 

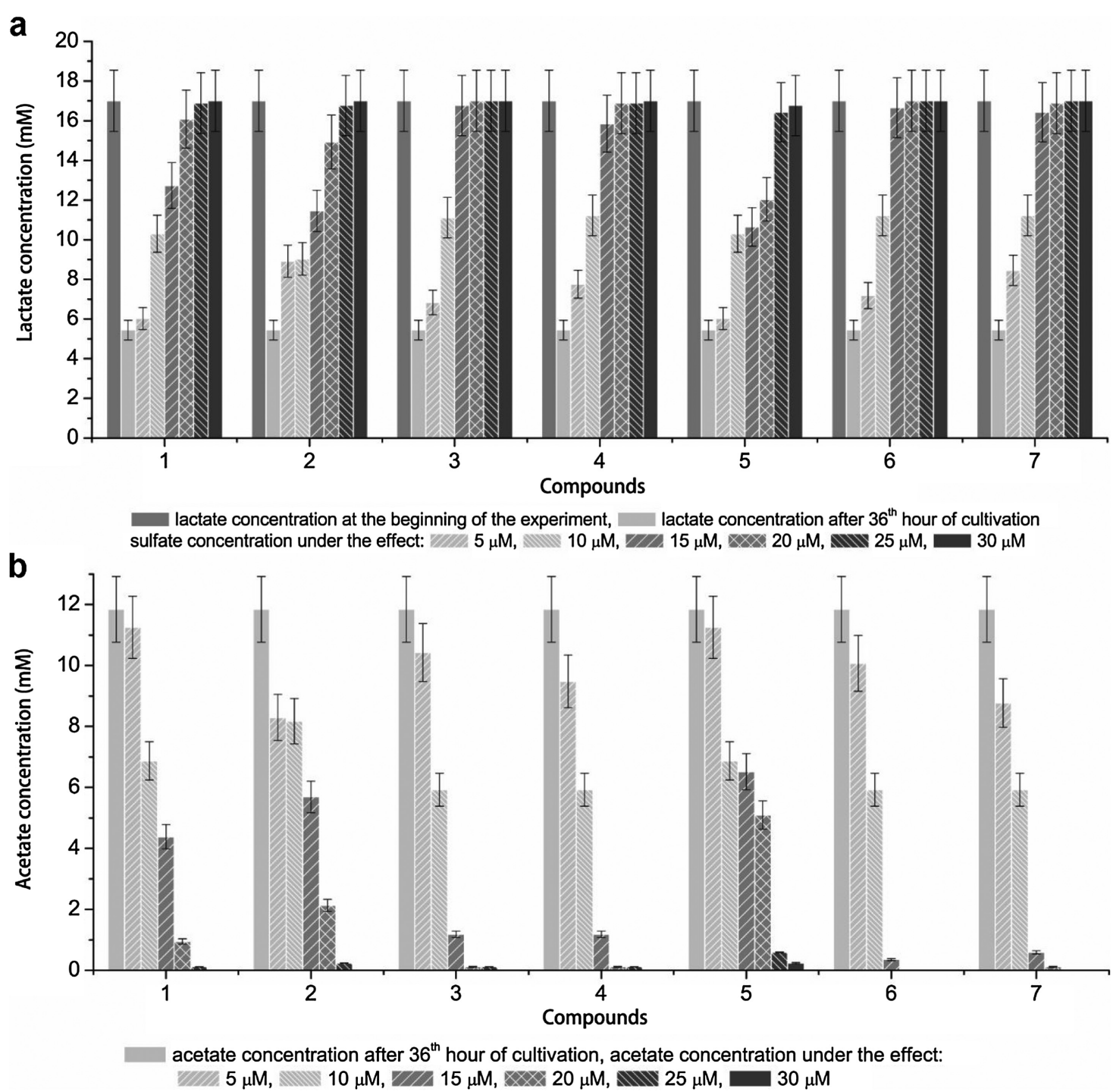

Fig. 3. The effect of ring-substituted 8-hydroxyquinoline-2-carboxanilides on lactate consumption (a) and acetate production (b) by D. piger Vib-7 cells.

The studied compounds are able to inhibit the number of sulfate-reducing bacteria and/or reduce the production of sulfide and acetate. This would help to clarify the factors influencing sulfide production in the human and animal colon.

\section{Conflict of interests}

The authors declare that they have no conflict of interests regarding the publication of this paper.

\section{Acknowledgements}

This study was supported by CZ.1.07/2.3.00/30.0053, APVV0516-12 and by Sanofi-Aventis Pharma Slovakia, s.r.o.

\section{References}

Bailey, N.T.J., 1995. Statistical Methods in Biology. Cambridge University Press. Barton, L.L., Hamilton, W.A., 2010. Sulphate-reducing Bacteria. Environmental and Engineered Systems. Cambridge University Press.

Brenner, D.J., Krieg, N.R., Staley, J.T., Garrity, G.M., 2005. Bergey's Manual of Systematic Bacteriology, second ed. The Proteobacteria, Part C: The Alpha-, Beta- Delta-, and Epsilonproteobacteria, Vol. 2. Springer, New York.
Cieslik, W., Musiol, R., Nycz, J.E., Jampilek, J., Vejsova, M., Wolff, M., Machura, B. Polanski, J., 2012. Contribution to investigation of antimicrobial activity of styrylquinolines. Bioorg. Med. Chem. 20, 6960-6968.

Cline, J.D., 1969. Spectrophotometric determination of hydrogen sulfide in natural water. Limnol. Ocean 14, 454-458.

Cummings, J.H., Macfarlane, G.T., Macfarlane, S., 2003. Intestinal bacteria and ulcerative colitis. Curr. Issues Intest. Microbiol. 4, 9-20.

Gibson, G.R., Cummings, J.H., Macfarlane, G.T., 1991. Growth and activities of sulphate-reducing bacteria in gut contents of health subjects and patients with ulcerative colitis. FEMS Microbiol. Ecol. 86, 103-112.

Gibson, G.R., Macfarlane, S., Macfarlane, G.T., 1993. Metabolic interactions involving sulphate-reducing and methanogenic bacteria in the human large intestine. FEMS Microbiol. Ecol. 12, 117-125.

Gonec, T., Bobal, P., Sujan, J., Pesko, M., Guo, J., Kralova, K., et al., 2012. Investigating the spectrum of biological activity of substituted quinoline-2-carboxamides and their isosteres. Molecules 17, 613-644.

Holt, J.G., Krieg, N.R., Sneath, P.H., 1994. Bergey's Manual of Determinative Bacteriology, ninth ed. Williams \& Wilkins, Philadelphia.

Jampilek, J., Kralova, K., Pesko, M., Kos, J., 2016. Ring-substituted 8hydroxyquinoline-2-carboxanilides as photosystem II inhibitors. Bioorg. Med. Chem. Lett. 26, 3862-3865.

Jampilek, J., 2017. Design of antimalarial agents based on natural products. Curr. Org. Chem. 21, 1824-1846.

Kolmert, A., Wikstrom, P., Hallberg, K.B., 2000. A fast and simple turbidimetric method for the determination of sulfate in sulfate-reducing bacterial cultures. J. Microbiol. Methods 41, 179-184.

Kos, J., Zadrazilova, I., Nevin, E., Soral, M., Gonec, T., Kollar, P., et al., 2015. Ringsubstituted 8-hydroxyquinoline-2-carboxanilides as potential antimycobacterial agents. J. Bioorg. Med. Chem. 23 (15) 4188-4096. 
Kushkevych, I., Fafula, R.V., 2014. Dissimilatory sulfite reductase in cell-free extracts of intestinal sulfate-reducing bacteria. Stud. Biol. 8 (2), 101-112.

Kushkevych, I., Bartos, M., Bartosova, L., 2014. Sequence analysis of the 16S rRNA gene of sulfate-reducing bacteria isolated from human intestine. Int. J. Curr. Microbiol. Appl. Sci. 3, 239-248.

Kushkevych, I., Kollar, P., Suchy, P., 2015a. Activity of selected salicylamides against intestinal sulfate-reducing bacteria. Neuroendocrinol. Lett. 36, 106-113.

Kushkevych, I., Fafula, R., Parak, T., Bartos, M., 2015b. Activity of Na+/K+-activated $\mathrm{Mg} 2+-$ dependent ATP hydrolase in the cell-free extracts of the sulfate-reducing bacteria Desulfovibrio piger Vib-7 and Desulfomicrobium sp. Rod-9. Acta Vet. Brno 84 (1), 3-12.

Kushkevych, I., Kollar, P., Ferreira, A.L., Palma, D., Duarte, A., Lopes, M.M., et al., 2016 Antimicrobial effect of salicylamide derivatives against intestinal sulfatereducing bacteria. J. Appl. Biomed. 14 (2), 125-130.

Kushkevych, I., 2012. Sulfate-reducing bacteria of the human intestine: I. Dissimilatory sulfate reduction. Stud. Biol. 6, 149-180.

Kushkevych, I., 2013. Identification of sulfate-reducing bacteria strains of human large intestine. Stud. Biol. 7, 115-124.

Kushkevych, I., 2014. Etiological role of sulfate-reducing bacteria in the development of inflammatory bowel diseases and ulcerative colitis. Am. J. Inf. Dis. Microbiol. 2 (3), 63-73.

Kushkevych, I., 2015a. Kinetic properties of pyruvate ferredoxin oxidoreductase of intestinal sulfate-reducing bacteria Desulfovibrio piger Vib-7 and Desulfomicrobium sp. Rod-9. Polish J. Microbiol. 64 (2), 107-114.

Kushkevych, I., 2015b. Activity and kinetic properties of phosphotransacetylase from intestinal sulfate-reducing bacteria. Acta Bioch. Pol. 62 (1), 1037-1108.

Kushkevych, I., 2016. Dissimilatory sulfate reduction in the intestinal sulfatereducing bacteria. Stud. Biol. 10 (1) 197-128.

Loubinoux, J., Mory, F., Pereira, I.A., Le Faou, A.E., 2000. Bacteremia caused by a strain of Desulfovibrio related to the provisionally named Desulfovibrio fairfieldensis. J. Clin. Microbiol. 38, 931-934.
Loubinoux, J., Bronowicji, J.P., Pereira, I.A., 2002a. Sulphate-reducing bacteria in human feces and their association with inflammatory diseases. FEMS Microbiol. Ecol. 40, 107-112.

Loubinoux, J., Valente, F.M.A., Pereira, I.A.C., 2002b. Reclassification of the only species of the genus Desulfomonas Desulfomonas pigra, as Desulfovibrio piger comb. nov. Int. J. Syst. Evol. Microbiol. 52, 1305-1308.

Mucaji, P., Atanasov, A.G., Bąk, A., Kozik, V., Sieron, K., Olsen, M., et al., 2017. The forty-sixth EuroCongress on drug synthesis and analysis: snapshot. Molecules 22, 1848.

Musiol, R., Jampilek, J., Buchta, V., Silva, L., Niedbala, H., Podeszwa, B., et al., 2006. Antifungal properties of new series of quinoline derivatives. Bioorg. Med. Chem. 14, 3592-3598.

Musiol, R., Jampilek, J., Kralova, K., Richardson, D.R., Kalinowski, D., Podeszwa, B., et al., 2007. Investigating biological activity spectrum for novel quinoline analogues. Bioorg. Med. Chem. 15, 1280-1288.

Musiol, R., Tabak, D., Niedbala, H., Podeszwa, B., Jampilek, J., Kralova, K., et al., 2008. Investigating biological activity spectrum for novel quinoline analogues 2 : Hydroxyquinolinecarboxamides with photosynthesis-inhibiting activity. Bioorg. Med. Chem. 16, 4490-4499.

Musiol, R., Jampilek, J., Nycz, J.E., Pesko, M., Carroll, J., Kralova, K., et al., 2010 Investigating the activity spectrum for ring-substituted 8-hydroxyquinolines. Molecules 15, 288-304.

Pitcher, M.C., Cummings, J.H., 1996. Hydrogen sulphide: a bacterial toxin in ulcerative colitis? Gut 39, 1-4.

Postgate, J.R., 1984. The Sulfate-Reducing Bacteria. Cambridge University Press.

Ranjith, P.K., Mary, S.Y., Panicker, Y.C., Anto, P.L., Armakovic, S., Armakovic, S.J., et al., 2017. New quinolone derivative: spectroscopic characterization and reactivity study by DFT and MD approaches. J. Mol. Struct. 1135, 1-14.

Rowan, F.E., Docherty, N.G., Coffey, J.C., O'Connell, P.R., 2009. Sulphate-reducing bacteria and hydrogen sulphide in the aetiology of ulcerative colitis. Br. J. Surg. 96, 151-158. 